\title{
Fish invading deserts: non-native species in arid Moroccan rivers
}

\author{
Miguel Clavero ${ }^{*}$, Javier Esquivias² ${ }^{2}$ Abdeljebbar Qninba ${ }^{3}$, María \\ Riesco $^{1}$, Javier Calzada4, Filipe Ribeiro ${ }^{5,6}$, Néstor Fernández ${ }^{1}$, Miguel \\ Delibes $^{1}$
}

1- Departamento de Biología de la Conservación. Estación Biológica de Doñana - CSIC. Av/ Americo Vespucio s.n. 41092 Sevilla, Spain

2- ECOTONO s.c.a. Núcleo residencial Santísima Trinidad, 8, bajo izq. 41008 Sevilla, Spain

3- Université Mohammed V-Agdal, Institut Scientifique, Av. Ibn Battota, B.P. 703 Agdal, Rabat, Morocco

4- Departamento de Biología Ambiental y Salud Pública, Universidad de Huelva, 21071 Huelva, Spain

5- Centro de Oceanografia, Faculdade de Ciências da Universidade de Lisboa, Campo Grande, 1749-016, Lisboa, Portugal

6- Universidade de Lisboa, Museu Nacional de História Natural e da Ciência, Rua da Escola Politécnica 58, 1269-102 Lisboa, Portugal

* Corresponding author: miguelclavero@ebd.csic.es

Running title: Non-native fish in pre-Saharan rivers 


\section{Abstract}

1. Desert rivers are highly dynamic systems in which dry periods, frequently involving the cessation of superficial flow, alternate with violent flash floods. In spite of their territorial importance and high functional and biological diversity, desert rivers have received little attention in the scientific literature, especially in Northern Africa.

2. This work reports the distribution of non-native fish, their relation with river damming and their potential impacts on native biodiversity in the main river basins draining arid areas of Morocco (Oued Draa, Oued Ziz and Oued Ghir), based on a field sampling covering 84 stream reaches.

3. Twelve fish species were detected, eight of which were non-native. Two species (stone moroko, Pseudorasbora parva, and bleak, Alburnus alburnus) had not been previously recorded in Morocco, while the native sandsmelt (Atherina boyeri) had not been cited as an invader. Pumpkinseed (Lepomis gibbosus) was the most widely distributed nonnative fish.

4. Non-native fish species were associated with reservoirs, colonising the regulated downstream reaches. Contrastingly, unregulated upstream reaches tended to be free of non-natives. The low abundance of native fish in reservoirs seems to be driven by the impacts of introduced fish species.

5. Management options for environmental flow are limited, due to reduced water availability. Non-native fish management should thus focus on limiting the spread of already introduced species and avoiding new introductions, especially into reservoirs.

Keywords: River, Stream, Biodiversity, Disturbance, Distribution, Fish, Alien Species, Impoundment 


\section{Introduction}

Arid and semiarid lands, where mean annual potential evapotranspiration is at least twice as large as annual mean precipitation, occupy over $30 \%$ of the world's land surface (Safriel and Adeel, 2005). Some of the most important rivers of the world as well as several minor river systems drain, either totally or in part, arid and semiarid areas (Kingsford and Thompson, 2006). These rivers (henceforth desert rivers) share the common features of water scarcity with variable duration, often with cessation of superficial water flow, and showing high temporal habitat variability (Stanley et al., 1997). Desert river systems have more diverse hydrological and physicochemical features than those in more mesic areas (Kingsford and Thompson, 2006; Harms et al., 2008).

Fish species in desert rivers are adapted to live in highly fluctuating ecosystems (Stanley et al., 1997; Bunn et al., 2006). Since most of these fish species lack droughtresistance adaptations (e.g. Dipnoi or lungfishes), their populations persist during dry periods in permanent pools that act as refugia. Conditions in these pools can be extreme, including hyperthermia, hypoxia and increased biotic interactions (e.g. Sternberg et al., 2012). There are also flash floods, which are proportionally more intense and more unpredictable in desert rivers compared to other rivers (Harms et al., 2008). These characteristics usually preclude the establishment of commonly introduced non-native fish species, usually evolved in more stable environmental conditions (Moyle and Light, 1996). However, the alteration of flow regimes due to human water uses, especially through river damming, can buffer the temporal variability of desert rivers (Kingsford, 2000) and thus facilitate the establishment and spread of non-native fish (Eby et al., 2003; Pool and Olden, 2014). Once established, non-native fish have driven declines of native species in different arid and semiarid areas of the world (Propst et al., 2008; Clarkson et al., 2012). 
Despite being a prominent component of the world's river systems and exhibiting a high diversity in their characteristics, desert rivers have been much less studied than rivers in wetter regions, with most of the existing knowledge derived from studies either in southwestern USA or in Australia (Harms et al., 2008). There is a scarcity of information on freshwater fish from Northern Africa, a region that encompasses important desert river systems (Smith and Darwall, 2006; Ribeiro and Leunda, 2012). Rivers in the arid areas of Morocco, Algeria and Tunisia are biogeographically interesting, since they host Mediterranean and Afrotropical affinities (Lévêque, 1990; Smith and Darwall, 2006; Qninba and Mataame, 2009). The latter are relict elements from wet times, when the current hyper-arid Sahara desert was a corridor for several freshwater species (Drake et al., 2011). The scarcity of information on the status of biodiversity in desert rivers is especially worrying in the light of the fragility of these systems. Pressure on water resources is severe in arid regions, where the subsistence of human societies relies on the use of a scarce and often unpredictable water supply (Kingsford, 2000). Northern African desert rivers are changing rapidly, including an increasing number of dams and the intensification of agricultural practices (García et al., 2010).

This work reports the status of non-native fish species in rivers and reservoirs of arid and semiarid regions of Morocco south of the High Atlas Mountains, based on an extensive field sampling. It also analyses the relationships between the patterns in the distribution of non-native fish and the presence of reservoirs, in order to investigate possible facilitation effects of these infrastructures. It is predicted that native species would be more prevalent in highly variable natural streams compared to reservoirs and regulated reaches with their relatively stable water levels. Finally, the possible current and future impacts of non-native fish on Northern African desert rivers and the options for their mitigation are discussed.

\section{Study area}


The study was conducted in the Draa, Ziz and Ghir basins, the main river systems that drain the southern slopes of the High Atlas (a mountain range, $>4000$ masl), east of Jbel Siroua. Annual precipitation, often falling as snow during winter, is relatively high (about $500-600 \mathrm{~mm}$ ) in this mountain range although eastern sectors are drier than western ones (Figure 1). As elevation diminishes, rivers flow through progressively more arid lands $(\leq 150 \mathrm{~mm})$ eventually infiltrating into the desert. Oued (river) Draa is the longest river in Morocco $(\sim 1100 \mathrm{~km})$. It has its own estuary in the Atlantic Ocean $(28.68 \mathrm{~N}, 11.12 \mathrm{~W})$, but superficial flow usually stops about $600 \mathrm{~km}$ upstream from the sea. With the name of Oued Dades (in Morocco rivers do not necessarily maintain the same name from source to mouth), it flows for almost 200km from the High Atlas south-westward. Then, already named Oued Draa, the river turns to flow south-eastward to cross the Jbel Saghro, the most important massif of the Anti-Atlas mountain range. In the region known as Coude du Draa (Draa's Elbow), the course of the river turns again to flow west to the sea, but in this stretch superficial flow usually stops. Middle reaches of Oued Draa only connect with its estuary during extreme rain episodes (Dłużewski and Krzemień, 2008). Ziz and Ghir basins, the other two rivers (Figure 1), flow from the High Atlas southwards, directly to the Sahara Desert. Although currently completely independent river basins, about 10000 years ago they formed part of one of the ancient lake systems that connected most perisaharian rivers, including the Niger River (Drake et al., 2011). Oued Ziz and its main tributary Oued Rheris, usually flow independently into the desert, but can connect near the Moroccan-Algerian border (30.64N, 4.43W) during high flow episodes. Oued Ghir enters Algeria shortly after or while joining its main tributaries (Oued Bouanane and Oued Zelmou, Figure 1) and flows for around 250km before disappearing under the Great Western Erg (Grand Erg Occidental, around 29.45N, 1.45W).

Agricultural lands are restricted to river banks and are irrigated by complex webs of channels (seguias) and occasionally also wells, usually mixing woody (almonds and nuts in high altitudes, date palms in lower lands) and herbaceous crops. Water salinity steadily 
increases downstream in the three basins, reaching on average $3000 \mu \mathrm{S} \times \mathrm{cm}^{-1}$, a threshold implying severe limitations for several crops, at around 800masl. There are three large dams in the three basins. El Mansour Eddahbi dam was built in 1972 in Oued Draa, with a maximum storage capacity of 529 million $\mathrm{m}^{3}$, more than half the average total annual flow of the river (Dłużewski and Krzemień, 2008). Hassan Addakhil dam was built in 1971 in the main course of Oued Ziz, with a total capacity of 347 million $\mathrm{m}^{3}$. The Djorf Torba dam in Algeria was built in 1969 in the main course of Oued Ghir, with a storage capacity of 299 million $\mathrm{m}^{3}$. There are also several minor dams (Dłużewski and Krzemień, 2008) and numerous small barriers across waterways that temporally retain or divert water. A new large dam on Oued Iriri, a tributary of the Oued Draa near El Mansour Eddaahbi dam, was

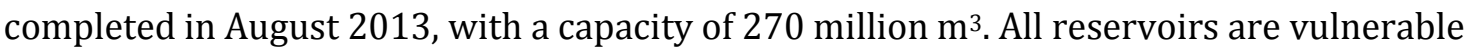
to siltation problems (Lahlou, 1996), with estimates that El Mansour Eddahbi and Hassa Addakhil reservoirs will be inoperative by about 2030 (Messouli et al., 2008; Busche, 2013)

\section{Data collection and analysis}

Fish were sampled in March and April 2013 in 84 sites (spring survey), 39 of which were re-sampled in September and October 2013 (autumn survey) (Figure 1). We measured water conductivity at each site and survey, with a HI 9828 multi-parameter instrument (Hanna Instruments, Italy). In most sites $(\mathrm{N}=64)$ a portable electrofishing device was used (model ELT60 II HI, Hans Grassl GmbH, Schönau am Königssee, Germany). About 100m of stream (mean 105.6m; range 35-400m) was sampled, using a single pass without blocking and direct pulse current (50-75 pulses $\left.\times \mathrm{s}^{-1}\right)$. Captured fish were kept in a meshed cage within the river, to avoid hypoxia. Whenever electrofishing could not be performed (e.g. in reservoirs or when water conductivity higher than $6000 \mu \mathrm{S}$ $\times \mathrm{cm}^{-1}$ ) we used fyke, seine and/or dip nets. Fyke nets had two different mesh sizes (3.5 
and $7 \mathrm{~mm}$ ) and were usually set for 24 hours. The seine nets were $5 \mathrm{~m}$ in length and $1.5 \mathrm{~m}$ in height, with a mesh size of $4 \mathrm{~mm}$.

Captured fish were identified to species, except for native Luciobarbus, which were identified only to genus, since taxonomy of Northern African barbels is currently unresolved (Crivelli, 2006). Arguably, barbels found in the Draa basin are L. lepineyi, while those in the Ziz and Ghir basins are L. pallaryi (J. Freyhof, pers. comm.), but the identity of species needs confirmation with molecular analyses (e.g. COI gene). Some of the basins may be inhabited by more than one barbel species. Total length was measured to the nearest mm before release, except a small sample taken for the collection of the Natural History Museum of the Institute Scientifique (Rabat, Morocco). The presence of external parasites or visible infections in captured fish was also noted.

Non-native status of fish species was defined attending to the role of humans in the presence of a species in the study area (e.g. transport). Any species occurring in the area due to the direct introduction by humans was considered non-native, even if it was native to other areas of northern Africa. The percentage of non-native fish individuals at each site indicated level of alteration of fish communities. In sites sampled twice (spring and autumn) these percentages were based on pooled data. The distance of each site along the river to the main reservoir, within each of the three basins, was measured using Google Earth. Distance was measured to the dam wall for downstream sites or to the maximum water level in reservoirs (estimated from changes in the vegetation) for upstream sites. Positive values were assigned to upstream distances and negative values to downstream ones. The relationship between this distance gradient and the presence of non-native fish species (presence/absence) was analysed using a generalized linear model with a binomial error distribution and a logit link function, while a simple linear regression was used for the relationship with the percentage of non-native fish individuals. Effect size for the generalized linear model was calculated as the percentage of deviance reduction 
between the null model (including only the intercept) and the model including distance to reservoir as explanatory variable. Unregulated tributaries, without reservoirs and joining regulated main rivers downstream from reservoirs (e.g., Oued Rheris and right margin tributaries of the middle Oued Draa), as well as sites where no fish were captured were excluded from the model.

\section{Results and discussion}

Native fish fauna

Fish were captured in 68 of the 84 sites visited in the spring survey and in 38 of the 39 sites visited in the autumn survey. Overall, 23401 individual fish were caught (10937 in spring and 12464 in autumn), including 13 fish species, five of which (assuming two barbel species) were native to the area (Table 1). Barbels were the most abundant and widely distributed fish in the studied rivers, present in 66 of the 68 sites in which fish were detected and clearly dominating fish communities in unregulated reaches, often the only taxon present.

Relict cichlid populations (of blue tilapia, Oreochromis aureus, and redbelly tilapia, Coptodon zillii) were exclusively recorded in the Draa basin. They occurred with barbel in Oued Tissint, a saline tributary of Oued Draa. The blue tilapia was also present in Oued Draa, up to 800 masl, possibly limited by cold winter temperatures registered at higher elevations. The present occurrence of redbelly tilapia or African jewelfish (Hemichromis bimaculatus) in the Ziz and Ghir basins (cited by Qninba and Mataame, 2009) could not be confirmed.

Brown trout (Salmo trutta) was detected in three sites over 1800masl, two belonging to the Draa basin (upper Oueds M'Goun and Dades) and one in Oued Sidi Hamza, a tributary of Oued Ziz. Trout populations from the Draa basin belong to a distinct, ancestral trout lineage (Dades lineage) isolated before the split of the two main groups of lineages 
(i.e. at least some 1.2 million years ago) (Snoj et al., 2011). These singular trout populations are highly vulnerable, due to their extreme southern location within trout distribution range and especially sensitive to global warming.

Two other native freshwater fish species occur in the studied basins, but were not recorded in the field sampling. European eel (Anguilla anguilla) occur in Oued Tissint, in the Draa basin, its southernmost distribution limit, although in small and declining numbers (Qninba et al., 2011). The the Sahara aphanius (Aphanius saourensis), is an endemic and critically endangered cyprinodontid (Azeroual, 2010), occurring in a single in the Ghir basin in Algeria (Blanco et al., 2006), about 200km south of our study area. It was once more widely distributed, potentially into the Moroccan part of Oued Ghir, but its range has contracted substantially, partly due to non-native species (Blanco et al., 2006).

\section{Non-native species and their distribution}

Eight non-native species were recorded in the study area (Table 1; Figure S1). The Draa and the Ghir basins had fivenon-native fish species, while only two were found in the Ziz basin. Most fish introductions in Morocco have occurred in the north (Mouslih, 1987), but results show that the studied desert rivers also have several non-native species. Azeroual (2003) cited the presence of two additional non-native fish species in the area, rudd (Scardinius erythrophthalmus) and grass crap (Ctenopharyngodon idella), but none were captured during the field sampling.

Two non-native species were recorded for the first time in Morocco: stone moroko (Pseudorasbora parva) and bleak (Alburnus alburnus) (Mouslih, 1987; Azeroual et al., 2000; Azeroual, 2003). They only occurred in the Ghir basin (Table 1), with goldfish (Carassius auratus). Goldfish were recorded in the 1950s, from the estuary of Oued Ksob (Furnestin et al., 1958), and in Oued Sebou in the early 1990s (Doadrio, 1994). Generally, the species is not included in the lists of non-native fish in Morocco (e.g. Azeroual et al., 2000). Prior to our work, there was scarce information about fish in the Ghir basin, which 
was not even represented in the reviews of Moroccan freshwater biodiversity (e.g., Azeroual et al., 2000; Dakki et al., 2009). These three non-native species had been recorded from Algeria (Kara, 2012), and so probably colonized Moroccan waters spreading from the neighbour country, possibly from Djorf Torba reservoir. Supporting this, bleak and goldfish occurred at the two sites closest to the Djorf Torba reservoir. Stone moroko have probably spread quickly through the Ghir basin (Figure 2). This species is a highly invasive Asian cyprinid now occupying most of Europe in less than 50 years, after its introduction in Romania in the 1960s (Gozlan et al., 2010). The species has been present in Northern Africa since the 1970s, but previously known localities are far from to the populations in the Ghir basin, with the closest located $750 \mathrm{~km}$ to the northeast, near Algiers (Gozlan et al., 2010). The range of stone moroko in Algeria is probably considerably larger than currently reported in the scientific literature.

Sandsmelt (Atherina boyeri) is a native species in Morocco, inhabiting wetlands and low river reaches (e.g. Azeroual, 2003; Francisco et al., 2008), but is non-native to the study area (Table 1), Sandsmelt is unlikely to have naturally colonised the study area, since it was mainly recorded in relatively high elevation reaches (>1100masl) and about $850 \mathrm{~km}$ of mostly dry river bed far from the sea sources. The species occurred in high numbers in El Mansour Eddahbi dam, where it formed large schools. It was also detected in two water courses just upstream of the reservoir, and occasionally along Oued Draa, below the dam (Figure 2). However, sandsmelt were rare and always scarce outside the reservoir. Inland, landlocked sandsmelt populations, from intentional or accidental releases, occur in endorheic lagoons (Fernández-Delgado and Hernando, 1982) and reservoirs (Pérez-Bote, 2002) in Spain and several reservoirs and lakes in Turkey (Innal and Erk'akan, 2006). However, sandsmelt had not been cited previously as a non-native species within Morocco. 
The distribution of common carp (Cyprinus carpio) followed a similar pattern to sandsmelt, although the species was rare, with only 12 individuals caught. All captured carps belonged to the mirror-like pool of artificially selected varieties (see Figure S1). Carp was introduced in Morocco in the mid-1920s and is currently common in many water bodies, from the sea level to high altitude lakes (Mouslih, 1987).

Pumpkinseed (Lepomis gibbosus) was the most widespread non-native fish in the area, found in all three surveyed basins (Figure 2). It was introduced in Morocco in the 1950s from North America (Mouslih, 1987), but the species had been present in Algeria since 1910, when it was introduced from France (Kara, 2012). In the study area, the species was abundant in reservoirs and close to reservoirs in upstream river stretches. Pumpkinseed also occurred in almost all river sites, often in high numbers, where flows were regulated by an upstream dam. This highly adaptable species may exploit anthropogenically altered aquatic systems (Fox et al., 2007). In the regulated parts of Oued Draa and Oued Ziz, dams reduce environmental variability and act as source of colonising individuals. However, there was one site in the unregulated Oued Rheris with a pumpkinseed population that probably originated due to a direct introduction (Figure 2). This site is separated by about $200 \mathrm{~km}$ of mostly dry river bed and highly saline stretches from the nearest pumpkinseed populations in Oued Ziz. Pumpkinseed occurred in sites with high water conductivity, up to $22900 \mu \mathrm{S} \times \mathrm{cm}^{-1}(\sim 13 \mathrm{ppt}$ in salinity), within the tolerance range reported for the species in estuarine habitats ( $\leq 17 \mathrm{ppt}$, Moyle, 2002). The species was particularly abundant in the Oued Rheris site (average of 53 fish per fyke net per day), where conductivity was over $10000 \mu \mathrm{S} \times \mathrm{cm}^{-1}$. Pumpkinseed may have arrived recently to the Ghir basin, since it was detected only in one site during the autumn survey and the population was almost completely dominated by young-of-the-year fish (average total length $=39.6 \mathrm{~mm}$; range $30-71 \mathrm{~mm} ; \mathrm{N}=42$ ). 
Mosquitofish (Gambusia holbrooki) were found mainly in Oued Draa around the Coud du Draa, where surface water usually disappears and conductivity is high (over $10000 \mu \mathrm{S} \times \mathrm{cm}^{-1}$ ), reflecting the high tolerance of the species (e.g. Ruiz-Navarro et al., 2013). Mosquitofish was especially abundant in the lowest sampled site along Oued Draa. The species was not recorded in the right margin tributaries of the middle Draa (Oued Tissint and Oued Tata), although Azeroual (2003) reported its presence in Oued Tata, where only barbels were found. Mosquitofish was present in Oued Zelmou, within the Ghir basin, with an abundant stone moroko population. Mosquitofish was introduced to Morocco in the late 1920s (Mouslih, 1987), arriving soon after in Algeria (Kara, 2012). Breeding facilities for the species for malaria control were established in 1928 in Rabat and Casablanca, followed by breeding centres across the country for widespread introduction (WHO, 2007). Mosquitofish stocking is still recommended in Morocco for malaria prevention (WHO, 2007).

Finally, largemouth bass (Micropterus salmoides) was only recorded in one of the three sites surveyed in the El Mansour Eddahbi reservoir. However, information provided by local fishermen indicated that the species was also present also in Hassan Addakhil reservoir.

\section{Reservoirs and non-native species}

Reservoirs were critically important for non-native fish in Moroccan desert rivers. Presence of non-native species had a clear sigmoidal response to the gradient of distance to the reservoir (Wald statistic $=12.6 ; \mathrm{N}=54 ; P<0.001 ; 47.2 \%$ variation explained), while the percentage of non-native individuals steadily increased along this gradient $[F=40.7$; $\mathrm{N}=50$ (i.e. excluding reservoir sites); $P<0.001 ; R^{2}=0.46$ ] (Figure 3). Upstream sites only had non-native species when near reservoirs but downstream sites were dominated by non-native species independently of distance to the reservoirs. Only 1 out of 15 sites below dams had no non-native fish species: this was a site in Oued Ziz strongly affected by 
organic pollution (effluents from the sewage treatment plant in the city of Errachidia) that was almost fishless (only 1 barbel captured).

Reservoirs favour invasion by being preferred sites for official and uncontrolled introductions (Johnson et al., 2008; Clavero and Hermoso, 2011). Reservoirs hold sport fishing activities, encouraging stocking of game and forage fish. Also, environmental conditions of reservoirs are more stable than in neighbouring river systems, especially in arid and semiarid regions (Godinho et al., 1998; Clavero et al., 2013). Non-native fish species are generally not adapted to the high variability of desert rivers, but can establish self-sustaining populations in reservoirs (Pool and Olden, 2014). The four reservoir sites were dominated by non-native fish species (Figure 4). Similarly, most introduced fish species were in reservoirs in arid areas of eastern Algeria (Chaibi et al., 2012). Results showed that reservoirs were also effective sources for colonization of the regulated downstream reaches by non-native species (Figure 3). Reductions in flow variability due to dams, including the softening offlash flood episodes, favour the establishment of nonnative species, mostly absent from unregulated rivers (Eby et al., 2003; Clavero et al., 2004). This was reflected by the relative poor colonisation of upstream unregulated river sectors by non-native fish species in our study, probably because of effects of floods (e.g. Meffe, 1984; Pool and Olden, 2014). Fish introduced to the Ghir basin colonized further upstream (up to $66 \mathrm{~km}$ ) than in the Draa or Ziz basins. This probably related to the lower gradient of Oued Ghir and its main tributaries, but also to the different pool of species present. Stone moroko or bleak may better colonize running water systems than largemouth bass or common carp. Also, non-native species could be favoured by the existence of relatively small dams, with capacity up to some 2 million $\mathrm{m}^{3}$ (Anonymous, 2013), which were probably artificially stocked, since local informants repeatedly explained that those small reservoirs contained "large fish".

\section{Potential impacts}


The impacts of non-native species are often difficult to identify due to the cooccurrence of several drivers of biodiversity loss (Didham et al., 2005). In our study area impacts of non-native species were confounded in time and space with altered flow regimes and more intensive agricultural practices. The presence of non-native fish was also much more common in lower reaches, and thus their effects could also be confounded with the natural longitudinal gradient. Furthermore, there is no reference condition information on the composition and structure of freshwater fish communities before dam construction or when non-native fish arrived, rendering evaluation of non-native fish impacts particularly difficult (Ribeiro and Leunda, 2012).

There were indicators that non-native fish had a negative effect on Moroccan desert river fish. There were few native species and in small numbers in reservoirs. Four reservoir sites were sampled (three in El Mansour Eddahbi and one in Hassan Addakhil) and captured 990 fish, including only five native fish (barbels; Figure 3). Barbels thus constituted $0.5 \%$ of the catch in reservoirs, while they were $91.6 \%$ of the catch in river stretches. Most Mediterranean barbels in the genus Luciobarbus, particularly those inhabiting desert rivers, are habitat generalists. They occupy environments that can change from a small, hot and crowded pool to a river with very high flow several times within a year. There should be no impediments for barbels to occupy reservoirs but they are rare in them probably excluded by largemouth bass predation, as recorded elsewhere (e.g. Clavero et al., 2013). The depletion of native prey populations by introduced piscivorous fish often favours new introduced species (e.g. Noble, 1981), probably explaining the stocking of sandsmelt in El Mansour Eddahbi reservoir. Mosquitofish is one of the main threats to the Sahara aphanius in the Algerian part of the Ghir basin (Azeroual, 2010). The probable direct impact of non-native fish on native species, particularly of mosquitofish, pumpkinseed and stone moroko on barbels and cichlids, remains to be analysed. In the absence of pre-invasion or environmentally similar reference condition, 
the study of these interactions should imply specifically-designed experimental approaches.

Non-native fish could also introduce fish parasites and other diseases (Gozlan et al., 2005; Peeler et al., 2011). Fish infected with the anchor worm Lernaea cyprinacea, a parasitic copepod, were found at 21 sites in the Draa and Ghir basins, the first report of the species for Morocco. This included 152 parasitized fish, mostly barbels (73.7\%), pumpkinseeds (21.7\%) and sandsmelts (4.6\%). The distribution of anchor worms was significantly associated with the presence of non-native fish species $\left(2 \times 2\right.$ table $\chi^{2}=16.89$; d.f. $=1 ; P<0.001 ; \mathrm{N}=68$, i.e. excluding fishless sites). L. cyprinacea was present in all reservoir sites and common in downstream sites and rare in upstream ones (Figure 4). Plausibly, its introduction was associated with introduction of non-native fish. $L$. cyprinacea is the most widely distributed of more than 100 anchor worm species, with an almost cosmopolitan range explained largely by human aided colonization linked to fish introductions (Lester and Hayward, 2006). The species had been previously recorded in Egypt (Mahmoud et al., 2009) and in central and southern African countries (AvenantOldewage, 2012), usually associated with non-native fish stocking.

The spread of stone moroko could also be associated with the arrival of the rosette agent (Sphaerothecun destruens), an intracellular parasite that causes high mortality in salmonids and cyprinids (Andreou et al., 2012), causing declines of native fish elsewhere (Gozlan et al., 2005).

\section{Management implications}

Most non-native fish were associated with reservoirs and modified flow regimes. The management of flow regimes to mimic natural frequency and magnitude of floods could be a powerful tool to control the non-native species populations in river reaches below dams (e.g. Freeman, 2002). This is unrealistic in arid Morocco, since water is a limiting resource for human populations and reservoir releases are strictly controlled (Messouli et al., 
2008). There is only one other option, avoidance of new introductions. Official stocking would need to cease, as well as reduction of uncontrolled introductions through policy and education strategies. It is especially important to avoid the introduction of new non-native species or any non-native species into the large reservoir recently built in Oued Iriri (Draa basin) (see Figure 1).

Where stocking occurs, rigorous audits for fish stocking activities should be established to stop the spread of non-native species (Davies et al., 2013). This may avoid the introduction of non-natives species already present in the country to Moroccan desert rivers (e.g. Mouslih, 1987), including species with serious economic impacts, such as the Asian clam (Corbicula fluminea) (Clavero et al., 2012). Stone moroko should be the target of these audits (Davies et al., 2013), to prevent the spread of this highly invasive, strongly impacting species (e.g. Gozlan et al., 2010) throughout unoccupied desert basins and other river systems within Morocco.

\section{Acknowledgments}

This study was funded by the National Geographic Society's Committee for Research and Exploration through grant \#9188-12 and benefitted by the support of Land Rover Jaguar España. Permission was obtained from the Haut Commissariat aux Eaux et Forêts et a à la Lutte Contre la Désertification du Royaume du Maroc. We greatly acknowledge the company and field assistance provided by R. Arroyo, C. Pérez, I. Soto, R. Becerra, M. A. Martínez, J. Borrero and M. Pérez. Comments by an anonymous reviewer and the editor greatly improved the manuscript. MC has a Ramón y Cajal contract funded by the Spanish Ministry of Science and Innovation. FR is supported by Portuguese Science Foundation (SFRH/BPD/46761/2008).

\section{Supporting information}

Figure S1. Photographs of non-native fish species recorded in the study area 


\section{References}

Andreou D, Arkush KD, Guégan JF, Gozlan RE. 2012. Introduced pathogens and native freshwater biodiversity: A case study of Sphaerothecum destruens. PLoS one 7: e36998

Anonymous. 2013. Le basin hydraulique de Guir-Bouânane. Les basin hydrauliques du Maroc. http://www.water.gov.ma/userfiles/file/12 Guir-déf.pdf [July 2013]

Avenant-Oldewage A. 2012. Lernaea cyprinacea and related species. In Fish parasites: pathobiology and protection, Woo PTK, Buchmann K (eds). CAB International: London; $337-349$

Azeroual A. 2003. Monographie des Poissons des eaux continentales du Maroc: systématique, distribution et écologie. PhD thesis, Université Mohammed V-Agdal, Rabat, Morocco

Azeroual A. 2010. Aphanius saourensis. In: IUCN 2013. IUCN Red List of Threatened Species. Version 2013.2. www.iucnredlist.org. [March 2014].

Azeroual A, Crivelli AJ, Yahyaoui A, Dakki M. 2000. L'ichtyofaune des eaux continentales du Maroc. Cybium 24(suppl. 3): 17-22

Blanco JL, Hrbek T, Doadrio I. 2006. A new species of the genus Aphanius (Nardo, 1832) (Actinopterygii, Cyprinodontidae) from Algeria. Zootaxa 1158: 39-53.

Bunn SE, Thoms MC, Hamilton SK, Capon SJ. 2006. Flow variability and dryland rivers: 'boom', 'bust' and the bits in between. River Research and Applications 22:179-186

Busche, HGK. 2013. Modeling hydrological processes in a semi-arid mountainous catchment at the regional scale. PhD thesis. Bonn University, Germany. 
Chaibi R, Si Bachir A, Chenchouni H, Boulêtreau S, Céréghino R, Santoul F. 2012. Effect of large-scale environmental variables and human pressure on distribution patterns of exotic continental fish in east Algeria. Zoology and Ecology 22: 166-171

Clarkson RW, Marsh PC, Dowling TE. 2012. Population prioritization for conservation of imperilled warmwater fishes in an arid-region drainage. Aquatic Conservation: Marine and Freshwater Ecosystems 22: 498-510

Clavero M, Blanco-Garrido F, Prenda J. 2004. Fish fauna in Iberian Mediterranean river basins: biodiversity, introduced species and damming impacts. Aquatic Conservation: Marine Freshwater Ecosystems 14: 575-585

Clavero M, Hermoso V. 2011. Reservoirs promote the taxonomic homogenization of fish communities within river basins. Biodiversity and Conservation 20: 41-57

Clavero M, Araújo R, Calzada J, Delibes M, Fernández N, Gutiérrez-Expósito C, Revilla E, Román J. 2012. The first invasive bivalve in African freshwaters: invasion portrait and management options. Aquatic Conservation: Marine Freshwater Ecosystems 22: $277-280$

Clavero M, Hermoso V, Aparicio E, Godino FN. 2013. Biodiversity in heavily modified water bodies: native and introduced fish in Iberian reservoirs. Freshwater Biology 58: 19901201

Crivelli AJ. 2006. Barbus pallaryi. In: IUCN 2012. IUCN Red List of Threatened Species. Version 2012.2. www.iucnredlist.org. [June 2013]

Dakki M, Himmi H, Qninba A, Benhoussa A, El Alami El Moutaouakil M. 2009. Faune aquatique continentale (invertébrés et poissons). Etude Nationel sur la Biodiversité. Observatoire National de l'Environnement du Maroc (ONEM) http://ma.chmcbd.net/implementation/doc product cdb ma/enb ma. [June 2013] 
Davies GD, Gozlan RE, Britton RJ. 2013. Can accidental introductions of non-native species be prevented by fish stocking audits? Aquatic Conservation: Marine and Freshwater Ecosystems 23: 366-373

Didham RK, Tylianakis JM, Hutchison MA, Ewers RM, Gemmell NJ. 2005. Are invasive species the drivers of ecological change? Trends in Ecology and Evolution 20: 470-474

Dłużewski M, Krzemień K. 2008. Physical geography of the Coude du Dra region. Prace Geograficzne 118: 23-36

Doadrio I. 1994. Freshwater fish fauna of North Africa and its biogeography. Annales Musee Royal de l'Afrique Centrale. Sciences Zoologiques 275 : 21-34

Drake NA, Blench RM, Armitage SJ, Bristow CS, White KH. 2011. Ancient watercourses and biogeography of the Sahara explain the peopling of the desert. Proceedings of the National Academy of Sciences, USA 108: 458-462

Eby LA, Fagan WF, Minckley WL. 2003. Variability and dynamics of a desert stream community. Ecological Applications 13: 1566-1579

Fernández-Delgado C, Hernando JA. 1982. Relaciones morfométricas de Atherina boyeri Risso (Pisces: Atherinidae) de la Laguna de Zóñar (Córdoba, España). Doñana, Acta Vertebrata 9: 13-25

Fox MG, Vila-Gispert A, Copp GH. 2007. Life-history traits of introduced Iberian pumpkinseed Lepomis gibbosus relative to native populations. Can differences explain colonization success? Journal of Fish Biology 71(suppl D): 56-69.

Francisco SM, Congiu L, Stefanni S, Congiu L, Brito A, Vieira MN, Almada VC. 2008. Phylogenetic relationships of the North-eastern Atlantic and Mediterranean forms of Atherina (Pisces, Atherinidae). Molecular Phylogenetics and Evolution 48: 782-788 
Freeman R. 2002. Harnessing the restoration potential of artifical floods. Conservation in Practice 3: 34-39

Furnestin J, Dardignac J, Maurin L, Vincent A, Coupe R, Boutiere H. 1958 Données nouvelles sur les poissons du Maroc atlantique. Revue des Travaux de l'Institut des Pêches Maritimes 22: 378-493

García N, Cuttelod A, Malak DA. 2010. The status and distribution of freshwater biodiversity in Northern Africa. IUCN: Gland, Cambridge and Málaga

Godinho FN, Ferreira MT, Portugal, Castro MI. 1998. Fish assemblage composition in relation to environmental gradients in Portuguese reservoirs. Aquatic Living Resources 11: 325-334.

Gozlan RE, St-Hilaire S, Feist SW, Martin P, Kent ML. 2005. Disease threat to European fish. Nature 435: 1046

Gozlan RE, Andreou D, Asaeda T, Beyer C, Bouhadad R, Burnard D, Caiola N, Cakic P, Dijikanovic K, Esmaeili HR, et al. 2010. Pancontinental invasion of Pseudorasbora parva, towards a better understanding of freshwater fish invasions. Fish and Fisheries 11: $315-340$.

Harms TK, Sponseller RA, Grimm NB. 2008. Desert Streams. In Ecosystems Jørgensen SE, Fath BD (eds). Encyclopedia of Ecology. Elsevier: Oxford; 871-879

Innal D, Erk'akan F. 2006. Effects of exotic and translocated fish species in the inland waters of Turkey. Reviews in Fish Biology and Fisheries 16: 39-50

Johnson PTJ, Olden JD, Vander Zanden MJ. 2008. Dam Invaders: impoundments facilitate biological invasions into freshwaters. Frontiers in Ecology and the Environment 6:357363 
Kara HM. 2012. Freshwater fish diversity in Algeria with emphasis on alien species.

European Journal of Wildlife Research 58: 243-253

Kingsford RT. 2000. Protecting rivers in arid regions or pumping them dry? Hydrobiologia 427: 1-11.

Kingsford RT, Thompson JR. 2006. Desert or dryland rivers of the world: an introduction. In The ecology of desert rivers Kingsford RT (ed). Cambridge University Press: Cambridge; 3-10

Lahlou A. 1996. Environmental and socio-economic impacts of erosion and sedimentation in North Africa. IAHS Publications-Series of Proceedings and Reports-Intern Assoc Hydrological Sciences 236: 491-500.

Lester RG, Hayward CJ. 2006. Phylum Arthropoda. In Fish diseases and disorders. Vol. 1: Protozoan and Metazoan Infections Woo PTK (ed). CAB International: London; 466565

Lévêque C. 1990. Relict tropical fish fauna in Central Sahara. Ichthyological Exploration of Freshwaters 1: 39-48.

Mahmoud MA, Aly SM, Diab AS, John G. 2009. The role of ornamental goldfish Carassius auratus in transfer of some viruses and ectoparasites to cultured fish in Egypt: comparative ultrapathological studies. African Journal of Aquatic Sciences 34: 111121.

Meffe GK. 1984. Effects of abiotic disturbance on coexistence of predator-prey fish species. Ecology 65: 1525-1534

Messouli M, Salem AB, Ghallabi B, et al. (2008). Ecohydrology and groundwater resources management under global change: A pilot study in the pre-Saharan basins of southern Morocco. In Technological perspectives for rational use of water resources in the 
Mediterranean region El Moujabber M., Mandi L, Liuzzi GT, et al. (eds). Options Méditerranéennes 88. CIHEAM: Bari; 255-266

Mouslih M. 1987. Introductions de poissons et d'écrevisses au Maroc. Revue d'Hydrobiologie Tropicale 20: 73-84

Moyle PB. 2002. Inland fishes of California. Revised and expanded. University of California Press: Berkley and Los Angeles

Moyle PB, Light T. 1996. Biological invasions of fresh water: empirical rules and assembly theory. Biological Conservation 78: 149-161.

Noble RL. 1981. Management of forage fishes in impoundments of the southern United States. Transactions of the American Fisheries Society 110: 738-750

Peeler EJ, Oidtmann BC, Midtlyng PJ, Miossec L, Gozlan RE. 2011. Non-native aquatic animals introductions have driven disease emergence in Europe. Biological Invasions 13: $1291-1303$.

Pérez-Bote JL. 2002. Estatus y conservación de la ictiofauna en Extremadura. Revista de Estudios Extremeños 58: 303-312

Pool TK, Olden JD. 2014. Assessing long-term fish responses and short-term solutions to flow regulation in a dryland river basin. Ecology of Freshwater Fish (in press) doi: 10.1111/eff.12125

Propst DL, Gido KB, Stefferud JA. 2008. Natural flow regimes, nonnative fishes, and native fish persistence in arid-land river systems. Ecological Applications 18: 1236-1252

Qninba A, Mataame A. 2009. Mise au point sur la répartition au Maroc des Cichlidés (Pisces, Perciformes) basée sur les échantillons conservés dans les collections du Muséum National d'Histoire Naturelle de l'Institut Scientifique (Rabat, Maroc). Bulletin de l'Institut Scientifique, Rabat, section Sciences de la Vie 31: 57-61 
Qninba A, Lieron V, Dieuleveut T, Amairat M, Yahyaoui A. (2011) Sur la présence de l'Anguille Anguilla anguilla (Linnaeus, 1758) dans l'Oued Tissint, un affluent de l'Oued Dr'a (Maroc). Bulletin de l'Institut Scientifique, Rabat, section Sciences de la Vie 33: 6566

Ribeiro F, Leunda PM. 2012. Non-native fish impacts on Mediterranean freshwater ecosystems: current knowledge and research needs. Fisheries Management and Ecology 19: 142-156.

Ruiz-Navarro A, Verdiell-Cubedo D, Torralva M, Oliva-Paterna FJ. 2013. Dilution stress facilitates colonization of invasive mosquitofish in a saline Mediterranean stream: population biology response. Aquatic Conservation: Marine Freshwater Ecosystems 23: $77-87$

Safriel U, Adeel Z. 2005. Dryland systems. In Ecosystems and human well-being: current state and trends Hassan R, Scholes R, Ash N (eds). Ecosystem Millennium Assessment, Island Press: Washington, DC; 623-662

Smith KG, Darwall WRT. 2006. The Status and distribution of freshwater fish endemic to the Mediterranean Basin. IUCN: Gland and Cambridge

Snoj A, Marić S, Bajec SS, Berrebi P, Janjani S, Schöffmann J. 2011. Phylogeographic structure and demographic patterns of brown trout in North-West Africa. Molecular Phylogenetics and Evolution 61: 203-211

Stanley EH, Fisher SG, Grimm NB. 1997. Ecosystem expansion and contraction in streams. BioScience 47: 427-435.

Sternberg D, Balcombe SR, Marshall JC, Lobegeiger JS, Arthington AH. 2012. Subtle 'boom and bust' response of Macquaria ambigua to flooding in an Australian dryland river. Environmental Biology of Fishes 93:95-104 
WHO (2007) Malaria in Morocco. Relentless efforts towards the goal of elimination.

Document WHO-EM/MAL/345/E. World Health Organization, Regional Office for the Eastern Mediterranean, and Royaume du Maroc, Ministère de la Santé. 
TABLE 1. Fish species recorded at 84 sites in Moroccan desert rivers, separated into native and non-native. For each species the number of sites ( $\mathrm{N}$ sites, from a total of 84 sampled sites, 68 of which had fish) and the basins where it was present are reported. DDraa basin; Z- Ziz basin; G- Ghir basin.

\section{Native species}

$\begin{array}{rrrcc}\text { Family } & \text { Species } & \text { Common name } & \text { N sites } & \text { Basins } \\ \text { Cichlidae } & \text { Coptodon zillii } & \text { Redbelly tilapia } & 3 & \mathrm{D} \\ \text { Cichlidae } & \text { Oreochromis aureus } & \text { Blue tilapia } & 9 & \mathrm{D} \\ \text { Cyprinidae } & \text { Luciobarbus spp } & \text { Barbels } & 66 & \mathrm{D}, \mathrm{Z}, \mathrm{G} \\ \text { Salmonidae } & \text { Salmo trutta } & \text { Brown trout } & 3 & \mathrm{D}, \mathrm{Z}\end{array}$

\section{Non-native species}

$\begin{array}{rrrcc}\text { Family } & \text { Species } & \text { Common name } & \text { N sites } & \text { Basins } \\ \text { Atherinidae } & \text { Atherina boyeri } & \text { Sandsmelt } & 8 & \mathrm{D} \\ \text { Centrarchidae } & \text { Lepomis gibbosus } & \text { Pumpkinseed } & 22 & \mathrm{D}, \mathrm{Z} \\ & \text { Micropterus salmoides } & \text { Largemouth bass } & 1 & \mathrm{D}\left(\mathrm{Z}^{*}\right) \\ \text { Cyprinidae } & \text { Cyprinus carpio } & \text { Common carp } & 6 & \mathrm{D} \\ & \text { Carassius auratus } & \text { Goldfish } & 2 & \mathrm{G} \\ & \text { Pseudorasbora parva } & \text { Stone moroko } & 3 & \mathrm{G} \\ & \text { Alburnus alburnus } & \text { Bleak } & 2 & \mathrm{G} \\ \text { Poecilidae } & \text { Gambusia holbrooki } & \text { Mosquitofish } & 4 & \text { D, G }\end{array}$

* Largemouth bass (Micropterus salmoides) was not captured in the Ziz basin, but it was reported there by local informants. 
FIGURE 1- Study area with relevant features, study sites and percentage of non-native fish individuals among fish catches. Upper panel: location of the three studied basin within northern Africa showing the 84 study sites (empty dots). Background tones represent mean annual precipitation. The rectangle shows in the location of subsequent panels. Middle panel: location of large reservoirs (empty circles) and main tributaries (filled rectangles) within the studied basins. Reservoirs: 1- El Mansour Eddahbi; 2- Hassan Addakhil; 3- Djorf Torba. Tributaries: 1- Oued Tata; 2_Oued Tissint; 3- Oued Zguid; 4Oued Ouarzazate; 5- Oued Dades; 6- Assif M'Goun; 7- Oued Todgha; 8- Oued Rheris; 9Oued Bouanane; 10- Oued Zelmou. Background tones represent elevation, with higher areas noted by lighter tones. Lower panel: percentage of non-native fish individuals among all fish captured at each site. Sites with no fish indicated with a filled star.

FIGURE 2- Distribution of eight non-native fish species (filled dots) in the three river basins, showing elevation (for legend, see Figure 1, lower panel)

FIGURE 3. Relationships of non-native fish species with a gradient of distance to reservoirs, showing negative distance values for downstream stretches and positive values for upstream sites. A) Position of sites with and without non-native fish species along the gradient. B) Variation in the percentage of non-native fish individuals along the gradient. The grey arrow marks the four reservoir sites included in the study.

FIGURE 4. Upper panel: distribution of Lernaea cyprinacea in the study area. Background tones represent elevation, with higher areas noted by lighter tones (see Figure 1). Photographs: Lernaea cyprinacea anchored on a sandsmelt (left) and between the pelvic fins of a pumpkinseed (right). 
FIGURE 1
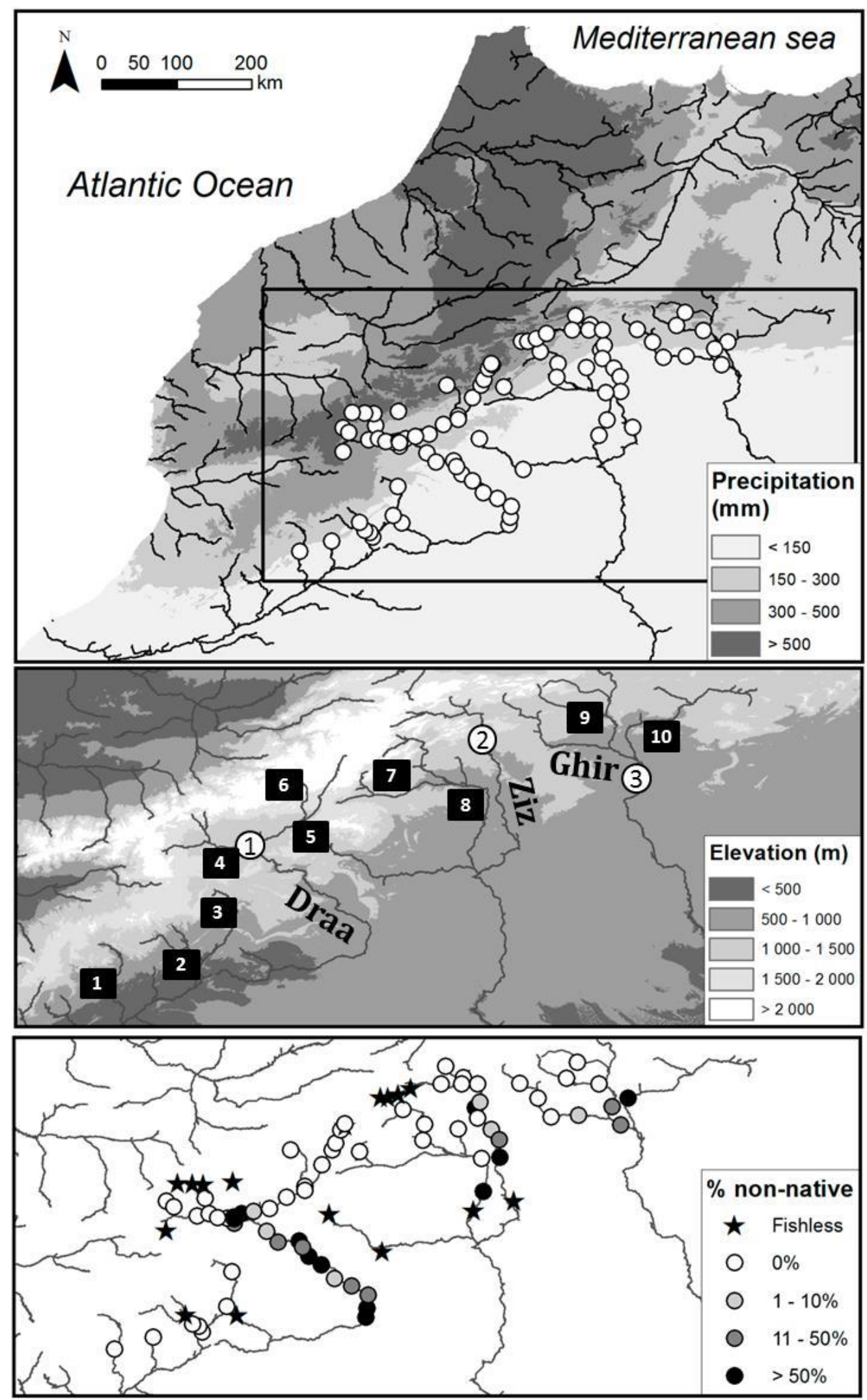
FIGURE 2
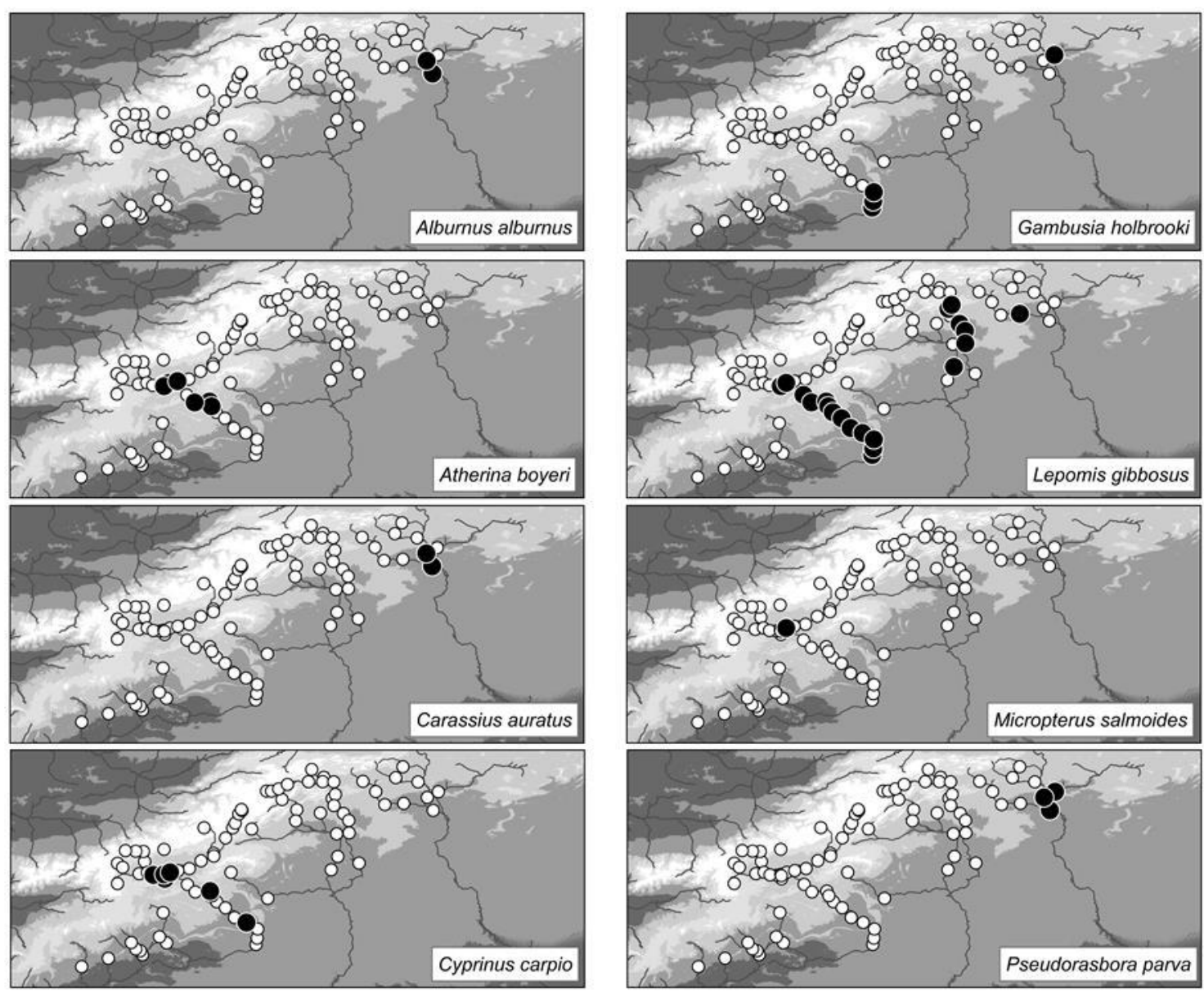
FIGURE 3

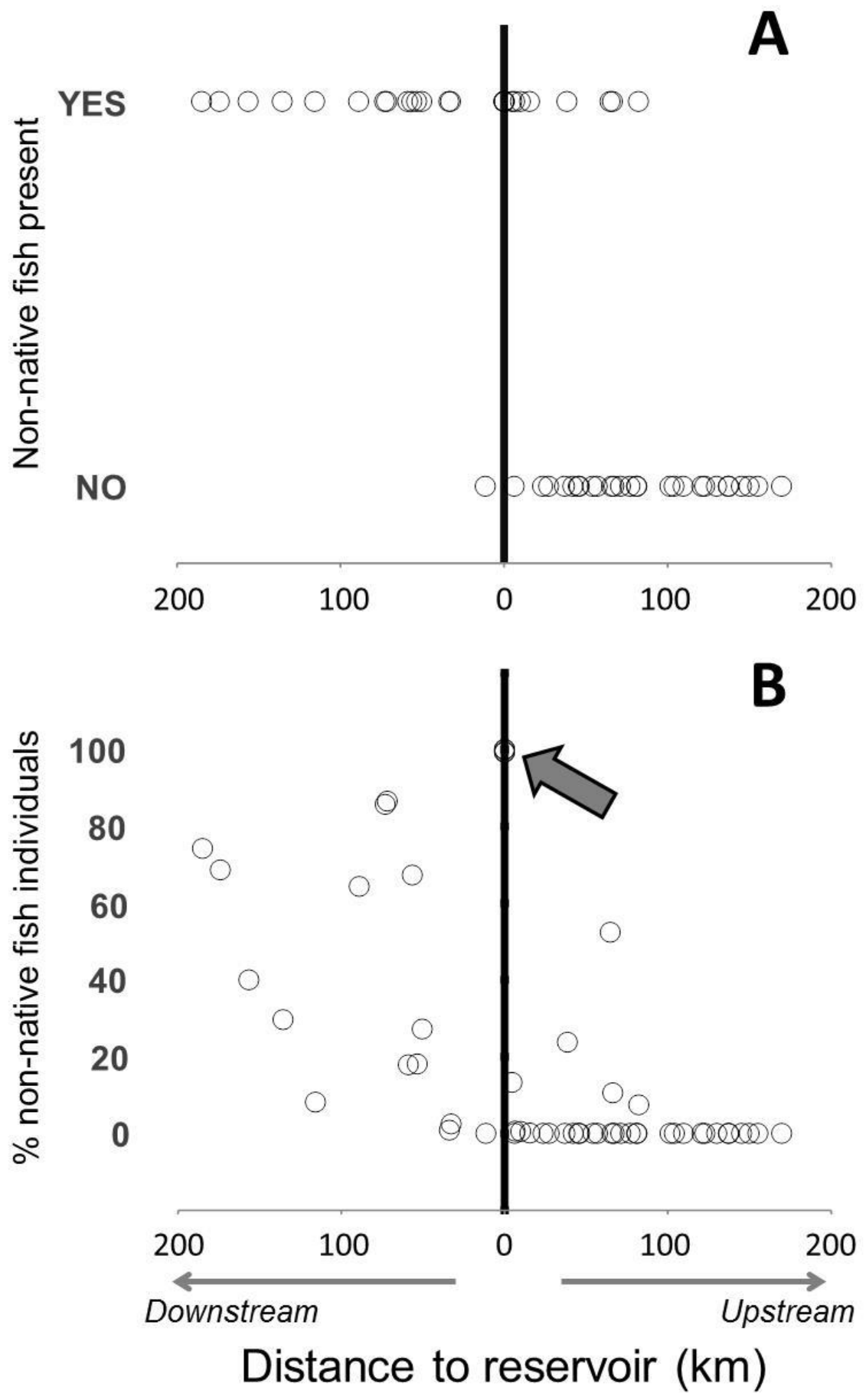


FIGURE 4
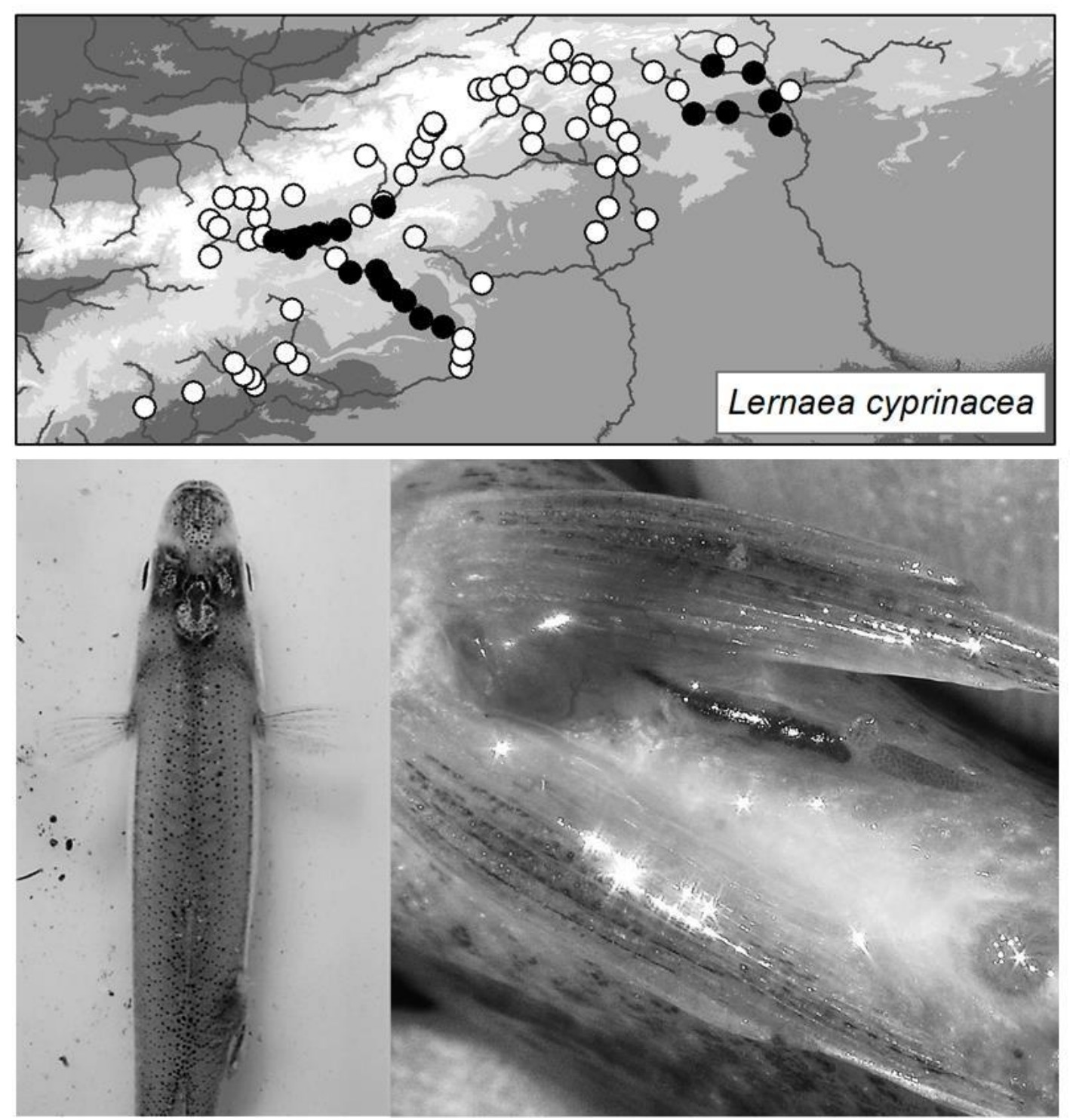